\title{
THE RELATIONSHIP OF ABILITY TO PAY AND OWNERSHIP OF HEALTH INSURANCE TOWARDS WILLINGNESS TO PAY LABORATORY SERVICES AT PERSAHABATAN HOSPITAL, EAST JAKARTA
}

\author{
Siska Putri Utami, Yanti Harjono Hadiwiardjo, Kristina Simanjuntak
}

Universitas Pembangunan Nasional "Veteran” Jakarta, Jakarta Selatan

\begin{abstract}
Background: Limited cost of health services, especially in laboratory tests for diagnoses, causes doctors to consider patient's willingness to pay so the costs are spent more efficiently. Some factors which supposedly affect the willingness to pay are ability to pay and health insurance ownership. This study aims to know the relationship between ability to pay and health insurance ownership with the willingness to pay for laboratory services in outpatients at RSUP Persahabatan.

Method: This research was an analytical observational research with cross-sectional design. Samples consisted of 70 outpatients at RSUP Persahabatan laboratory collected by consecutive sampling. The dependent variable is willingness to pay and the independent variable are the ability to pay and insurance ownership measured using a questionnaire. The data was analyzed by Chi-square.

Results: Chi-square test results showed relationship between the ability to pay and the willingness to pay for laboratory health services $(\mathrm{OR}=13.14 ; 95 \% \mathrm{CI}=2.76$ to $62.49 ; \mathrm{p}<0.001)$. There was no relationship between health insurance ownership and the willingness to pay for laboratory health services $(\mathrm{OR}=2.82 ; 95 \% \mathrm{CI}=0.85$ to 9.33; $\mathrm{p}=0.083)$.

Conclusion: High ability to pay will lead to high willingness to pay, since their need for food has been met and they will shift to the need for health. The health insurance ownership does not affect the willingness of patients in paying laboratory service.
\end{abstract}

Keywords: Ability to Pay, Health Insurance, Hospital, Laboratory Services, Willingness to Pay.

Correspondence:

Siska Putri Utami. Medicine Study Program, Medicine Study Program, Faculty of Medicine, UPN "Veteran" Jakart. Jl. RS. Fatmawati Raya, Pd. Labu, Cilandak district, Depok, West Java, 12450. Email: Thesiska07@gmail.com. Phone: (021) 7656971

The $7^{\text {th }}$ International Conference on Public Health Solo, Indonesia, November 18-19, 2020 | 333 https://doi.org/10.26911/the7thicph.04.18 